\title{
Apoptosis of Sertoli cells after conditional ablation of murine double minute 2 (Mdm2) gene is p53-dependent and results in male sterility
}

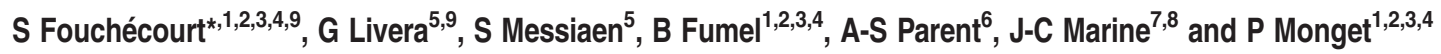

Beside its well-documented role in carcinogenesis, the function of p53 family has been more recently revealed in development and female reproduction, but it is still poorly documented in male reproduction. We specifically tested this possibility by ablating Mdm2, an E3 ligase that regulates p53 protein stability and transactivation function, specifically in Sertoli cells (SCs) using the AMH-Cre line and created the new SC-Mdm2 ${ }^{-l-}$ line. Heterozygous SC-Mdm2 ${ }^{-{ }^{\prime+}}$ adult males were fertile, but SC$M \mathrm{Mm} 2^{-I-}$ males were infertile and exhibited: a shorter ano-genital distance, an extra duct along the vas deferens that presents a uterus-like morphology, degenerated testes with no organized seminiferous tubules and a complete loss of differentiated germ cells. In adults, testosterone levels as well as StAR, P450c17 (Cyp17a1) and P450scc (Cyp11a1) mRNA levels decreased significantly, and both plasma LH and FSH levels increased. A detailed investigation of testicular development indicated that the phenotype arose during fetal life, with SC-Mdm2 ${ }^{-1-}$ testes being much smaller at birth. Interestingly, Leydig cells remained present until adulthood and fetal germ cells abnormally initiated meiosis. Inactivation of Mdm2 in SCs triggered p53 activation and apoptosis as early as $\mathbf{1 5 . 5}$ days post conception with significant increase in apoptotic SCs. Importantly, testis development

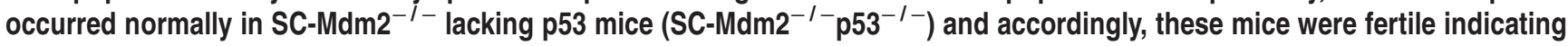
that the aforementioned phenotypes are entirely p53-dependent. These data not only highlight the importance of keeping p53 in check for proper testicular development and male fertility but also certify the critical role of SCs in the maintenance of meiotic repression.

Cell Death and Differentiation (2016) 23, 521-530; doi:10.1038/cdd.2015.120; published online 16 October 2015

Sertoli cells (SCs) are the supporting cell lineage of the male germ line and their function is critical for male fertility. SCs differentiate early during fetal life; they are the first cells that differentiate in the testes and they drive the sexual differentiation of the gonad (for review, see Svingen and Koopman ${ }^{1}$ ). In the mouse, these cells start forming cords by enclosing germ cells as early as 12 days post conception. SCs are responsible for providing germ cells with a specialized environment to promote their survival and orchestrate their differentiation throughout life. They also allow the differentiation of Leydig cells through paracrine signaling, including Desert hedgehog signaling, for example, ${ }^{2}$ and promote their activity. ${ }^{3}$ SCs are involved in masculinizing the embryo as they produce high levels of anti-Müllerian hormone $(\mathrm{AMH})$ that triggers the regression of the future female genitalia. Strikingly, SCs only proliferate during fetal and post-natal life, and definitively cease cycling around 10 days postpartum. Interestingly, these cells are relatively resistant to apoptosis in response to DNA damage. It has been proven in developing rat testes that these cells easily survive a high dose of radiation exposure. ${ }^{4}$ The mechanisms underlying the poor responsiveness of SCs to DNA damage remains elusive. In the human embryonic testis, the mild apoptotic response of SCs following radiation is decreased by pharmacological inhibition of p53 with pifithrin alpha. $^{5}$

The role of p53 has been largely documented as the 'guardian of the genome'; owing to its deregulation in numerous cancers, it is considered as a major tumor suppressor. From a model organism, it appears that p53 homologs are also key regulators of development and reproduction. Interestingly in mammals, p53-related proteins (i.e., p63 or p73) are also involved in the development of the central nervous system. Inactivation of any of the three p53 family members impairs mouse female fertility. ${ }^{6,7}$ On the other hand, the data relating p53 to male fertility are still scarce. So far, in testis, the function of p53 is little documented, except in testicular germ cell tumors ${ }^{8}$ and germ cell apoptosis (apoptosis of prenatal sperm cells ${ }^{9}$ and of damaged sperm in the adult $^{10}$ ). The murine double minute 2 gene $\mathrm{Mdm} 2$ belongs to a large family of RING finger-containing proteins,

\footnotetext{
${ }^{1}$ INRA, UMR85 Physiologie de la Reproduction et des Comportements, F-37380 Nouzilly, France; ${ }^{2}$ CNRS, UMR6175 Physiologie de la Reproduction et des Comportements, F-37380 Nouzilly, France; ${ }^{3}$ Université François Rabelais de Tours, F-37041 Tours, France; ${ }^{4}$ IFCE, F-37380 Nouzilly, France; ${ }^{5}$ Laboratoire de Développement des Gonades, INSERM U967, CEA/DSV/iRCM/SCSR/LDG, Univ Paris Diderot, Sorbonne Paris Cité, F-92265 Fontenay-Aux-Roses, France; ${ }^{6}$ Developmental Neuroendocrinology Unit, GIGA Neurosciences, University of Liège, CHU Sart Tilman, Liège, Belgium; ' Laboratory for Molecular Cancer Biology, Center for Human Genetics, KU Leuven, Leuven, Belgium and ${ }^{8}$ Center for the Biology of Disease, VIB, Leuven, Belgium

${ }^{*}$ Corresponding author: S Fouchécourt, INRA, UMR85 Physiologie de la Reproduction et des Comportements, F-37380 Nouzilly, France. Tel: +33 (0) 247427271 ; Fax: +33 (0) 247427 743; E-mail: sophie.fouchecourt@tours.inra.fr

${ }^{9}$ These authors contributed equally in this work.

Abbreviations: SCs, Sertoli cells; Mdm2, Murine double minute 2; AGD, Ano-genital distance; En, embryonic age $n$; Pn, post-natal age $n$

Received 19.12.14; revised 03.7.15; accepted 31.7.15; Edited by M Oren; published online 16.10.15
} 
and functions mainly as an E3 ligase regulating the activity of various substrates by ubiquitylation (mono- or poly- ubiquitylation). Among the substrates is the p53 tumor suppressor, which is responsible for transcriptional activation of genes involved in the cell cycle, apoptosis and cell aging. ${ }^{11-13}$ Overexpression of Mdm2 is one of the mechanisms that leads to $p 53$ inactivation by promoting its proteasome-dependent degradation after ubiquitylation in the tumors that retain wildtype p53 (for review, see Marine and Lozano ${ }^{14}$ ). In addition, Mdm2 can bind the p53 transactivation domain and directly interfere with p53 transcriptional regulatory mechanisms. Mdm2-null mice are not viable because of early embryonic lethality (E3.5), but are viable in a p53-null background. ${ }^{15,16}$ To test whether the suppression of p53 function is required for testicular development and male fertility, we inactivated specifically Mdm2 in SCs using the AMH-Cre line. ${ }^{17}$

\section{Results}

Mdm2 mRNA was detected in testes (adult and P10) and was present in SC-enriched fractions from prepubertal P10 mice (Supplementary data 1). To test the hypothesis of the critical role of Mdm2 in SCs, we created a transgenic line with targeted invalidation of Mdm2 specifically in SCs by crossing $\mathrm{AMH}-\mathrm{Cre}$ and $\mathrm{Mdm}^{\mathrm{LL}}$ lines, and named this new line SC$\mathrm{Mdm}^{-1-}$. The contemporary Cre-Mdm2 $2^{\mathrm{LL}}$ littermate controls were called Cre-. We verified that the allele lacking exons 5 and 6 (Mdm2[Sexons5/6]) after the Cre recombination event (226 bp) was detected in testes but not in any other tissues (Supplementary data 2).

At adulthood (3 months), SC-Mdm2 $2^{-1-}$ males were infertile and had very small testes (Figures 1a-d; testis weight: SC-Mdm2 ${ }^{-/-} 5.35 \mathrm{mg}^{\star \star \star} \pm 1.40$ versus Cre- $112.8 \mathrm{mg} \pm 4.5$, $P<0.001$ ), an abnormal external genital tract and a shorter ano-genital distance compared with Cre- (Figures $1 \mathrm{~g}$ and $\mathrm{h}$ ). Conversely, heterozygous SC-Mdm2 ${ }^{-/+}$males were normally fertile and had a normal genital tract (not shown). Testicular histology in adult SC-Mdm2 ${ }^{-/-}$(Figure 2A) was characterized by the absence of seminiferous tubule organization and differentiated germ cells.

Seminal vesicles and epididymides were significantly smaller in SC-Mdm2 $2^{-/-}$than in Cre- (seminal vesicle weight: SC-Mdm2 ${ }^{-/-} 137.7 \mathrm{mg}^{\star \star *} \pm 22.2$ versus Cre- $448.5 \mathrm{mg} \pm 30.7$, $P<0.001$; epididymis weight: SC-Mdm2 ${ }^{-/-} 30.3 \mathrm{mg}^{\star \star \star} \pm 4.84$
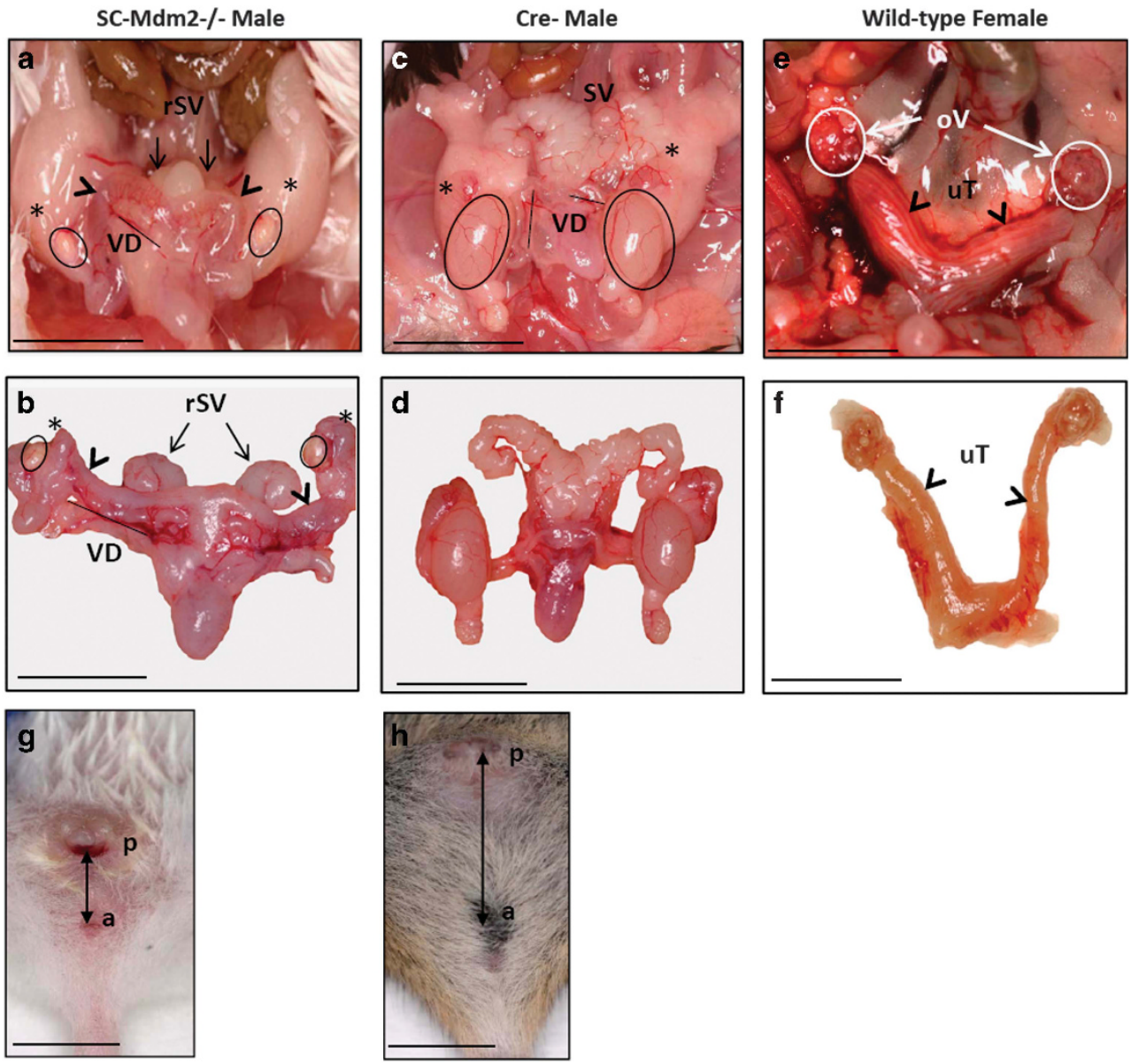

Figure 1 Internal genital tract of SC-Mdm2 ${ }^{-/-}$males ( $\mathbf{a}$ and $\mathbf{b}$ ) compared with Cre- (c and $\mathbf{d}$ ) and normal female tracts (e and $\left.\mathbf{f}\right)$. Black circles are positioned on testes, stars on the caput of the epididymis, and arrowheads on the extra ducts present in SC-Mdm2 ${ }^{-1-}(\mathbf{a}, \mathbf{b})$ and the uterus in females (e). SV: seminal vesicles; rSV: reduced seminal vesicles; VD: vas deferens. Ov: ovary (E: white circles); uT: uterus. External genital tract of SC-Mdm2 ${ }^{-1-}$ males $(\mathbf{g} / \mathbf{h})$. Arrows show the AGD in SC-Mdm2 ${ }^{-1-}(\mathbf{g})$ and Cre- $(\mathbf{h})$ males. $\mathrm{a}=$ anus, $p=$ penis. Bar represents $1 \mathrm{~cm}$ 

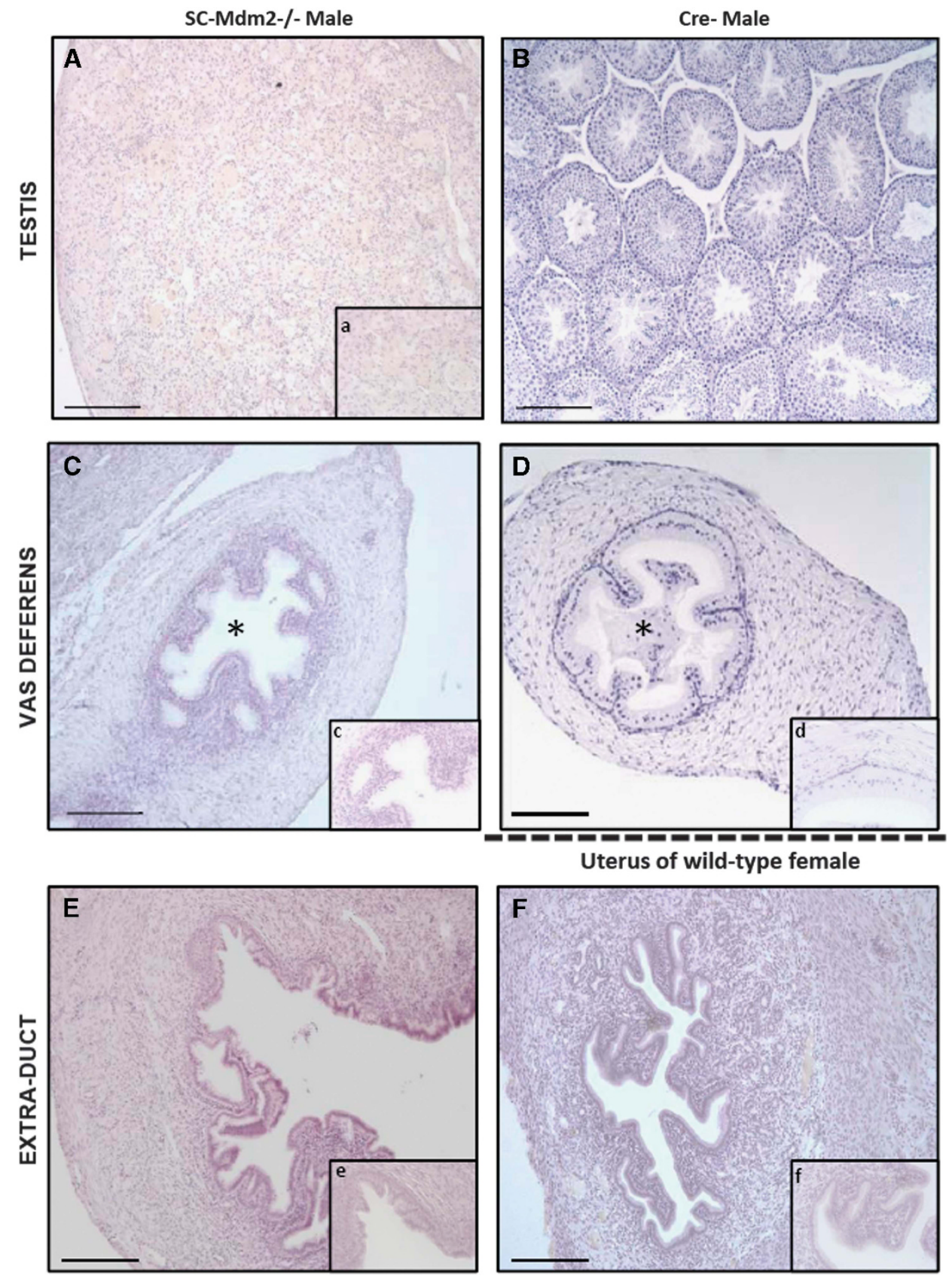

Figure 2 Histology sections (hematoxylin staining) of testes and ducts in adult SC-Mdm2 ${ }^{-1-}$ males (A, C, E) compared with Cre- males for testes and vas deferens (B, C) and females for uterus $(\mathbf{E}, \mathbf{F})$. Testicular cells were not organized in seminiferous tubules in adult SC-Mdm2 ${ }^{-1}$ testes $(\mathbf{A}, a)$ and no differentiated germ cells were present. No sperm was present in the lumen $\left(^{*}\right)$ of the vas deferens contrary to $\mathrm{Cre}-(\mathbf{C}, \boldsymbol{c}$ and $\mathbf{D}, d)$. The histology of the extra duct was similar to the uterus $(\mathbf{E}, e$ and $\mathbf{F}, f)$. Bar in large windows represents $100 \mu \mathrm{m}$; magnification is four times greater in small windows $(a, c, d, e, f)$

versus Cre- $48.6 \mathrm{mg} \pm 2.2, P<0.001$ ) (Figure $1 \mathrm{a}-\mathrm{d}$ ). Interestingly, we observed an extra duct along the vas deferens with the apparent aspect of a uterus (Figures 1a, b, e and f) and histology similar to the uterus (Figures $2 \mathrm{E}$ and $\mathrm{F}$ ); the histology of the vas deferens was normal (Figures $2 \mathrm{C}$ and $\mathrm{D}$ ); no sperm was present in the lumen.

In correlation with a decrease in seminal vesicle weight, plasma testosterone levels significantly decreased in SC$\mathrm{Mdm}^{-/-}$(Figures 3a, $n=8$ for each genotype), along with mRNA levels per testis of Cyp17a1 (P450c17), Cyp11a1
(P450scc) and StAR (Figure 3b, $n=5$ for each genotype). Consequently, LH levels significantly increased by a factor of around 7 in SC-Mdm2 ${ }^{-1-}$ compared with Cre- (Figure 3c; $P<0.001)$. Interestingly, FSH levels also significantly increased in SC-Mdm2 ${ }^{-1-}$ (Figure $3 \mathrm{~d}$; $P<0.001$ ).

As $\mathrm{AMH}-\mathrm{Cre}$ is expected to induce the deletion of the Mdm2 allele during fetal life (around E15), we sought to determine the precise kinetics of the appearance of this phenotype. Testes were harvested at various stages during fetal (E15, E16, E18) and post-natal life (P1) (Figures 4-7). The analysis of 

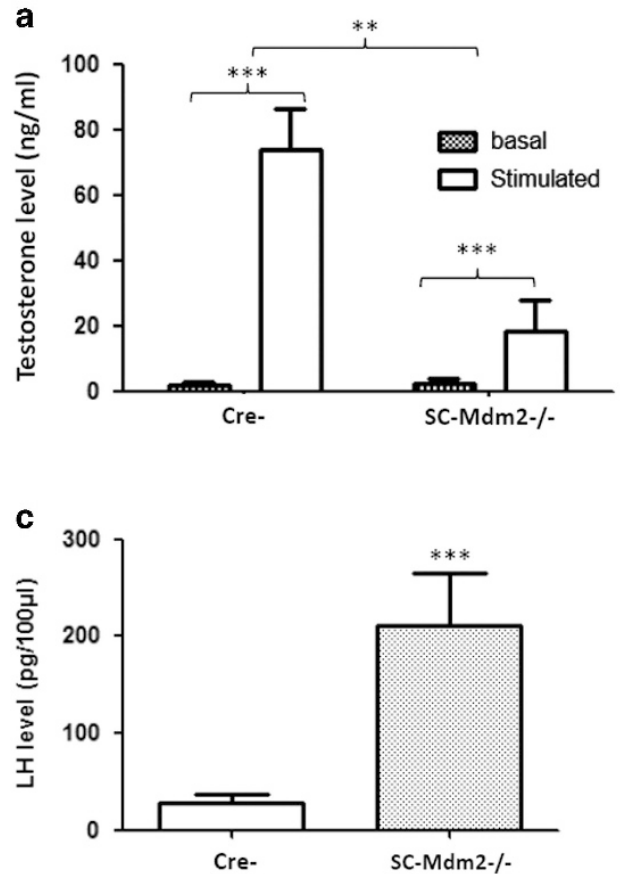

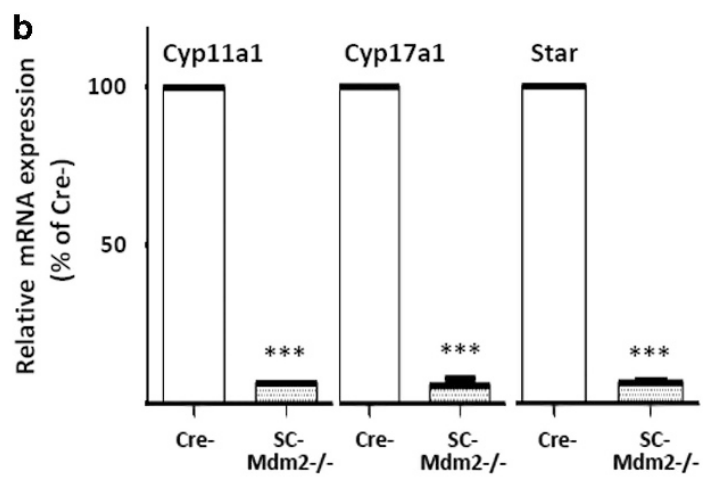

d

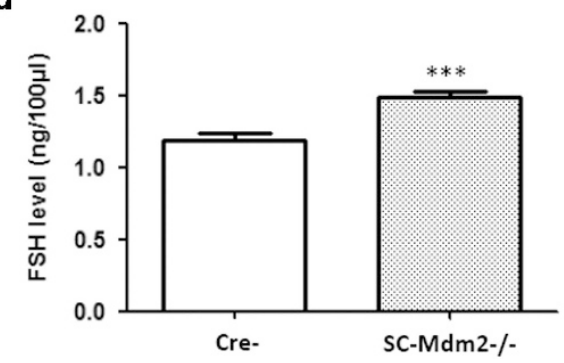

Figure 3 SC-Mdm2 ${ }^{-1-}$ hormonal status. (a) Plasma testosterone levels in adult SC-Mdm2 ${ }^{-1-}$ males, in basal conditions and after human chorionic gonadotropin (hCG) stimulation. In both SC-Mdm2 ${ }^{-1-}$ and Cre- (8 males for each genotype), hCG induced a significant increase $\left({ }^{\star \star \star} P<0.001\right)$ in testosterone secretion, as expected. Plasma testosterone levels decreased significantly in SC-Mdm2 ${ }^{-1}$ compared with Cre- $\left(^{* \star} P<0.01\right)$. Data shown as mean $+/-$ S.E.M.; statistical analyses: two-way ANOVA followed by Bonferroni's post hoc test; hatching: basal levels; white: hCG stimulated levels. (b) SC-Mdm2 ${ }^{-1-}$ testes exhibit a decrease in mRNA levels of Cyp17a1 (P450c17), Cyp11a1 (P450scc) and StAR. The amounts of mRNA of the three steroidogenic genes were compared between SC-Mdm2 ${ }^{-1}-$ and Cre- $(n=5$ mice for each genotype, tested in triplicate) using TaqMan quantitative real-time PCR as described in Materials and Methods. Normalization was performed with two housekeeping genes, $\beta$-actin and GAPDH, that both exhibited similar expression between samples. Results are presented as \% of mRNA level in Cre- (100 is arbitrary level for whole Cre- testes) and a non-parametric test (Mann-Whitney) was chosen for the statistical analysis ( $\left.{ }^{\star * \star} P<0.001\right)$. White: Cre-; hatching: SC-Mdm2 ${ }^{-1-}$. (c) LH levels in SC-Mdm2 ${ }^{-1-}$ males: plasma LH concentrations expressed in pg/100 $\mu \mathrm{l}$ in Cre- $(n=13)$ and SC-Mdm2 ${ }^{-1-}(n=19)$ determined by RIA. (d) FSH levels in SC-Mdm2 ${ }^{-1-}$ males: plasma FSH concentrations expressed in $\mathrm{ng} / 100 \mu \mathrm{l}$ in Cre- $(n=16)$ and SC-Mdm2 ${ }^{-1-}(n=23)$ determined by RIA. Data shown as mean $+/-$ S.E.M. Statistical analysis: Mann-Whitney test $\left(^{* \star \star} P<0.001\right)$. White: Cre-; hatching: SC-Mdm2 ${ }^{-/-}$

sections at $\mathrm{P} 1$ already indicated a pronounced reduction in gonad size $\left(0.10 \mu \mathrm{l}^{* *} \pm 0.01\right.$ versus $0.38 \mu \mathrm{l} \pm 0.02 \mu \mathrm{l}, n=4$, $P<0.01$, respectively, for SC-Mdm2 $2^{-/-}$and the control) with an almost total loss of cord structures. Testicular cord disappearance was similarly pronounced at E18, while a few cords could still be retrieved at E16 and E15. To understand this phenomenon, apoptosis was investigated by observing TUNEL (Figures 4 and 5) and cleaved-caspase 3 (Figure 6). Both methods similarly revealed numerous apoptotic cells in the SC-Mdm2 $2^{-1-}$ testes at all the stages examined (e.g., $29 \pm 11$ versus $150 \pm 22$ cells $/ \mathrm{mm}^{2}, n=4$, respectively, for the control and SC-Mdm2 ${ }^{-/-}$at P1). Interestingly, double $\mathrm{AMH}$ TUNEL staining clearly indicated that dying cells were mostly SCs at E15 and E16 (Figure 4). Quantification of AMH-TUNEL cells evidenced a significantly increased apoptosis $(1.2 \pm 0.7$ versus $37.2 \pm 2.7 \%, n=3-5$, respectively, for the control and SC-Mdm2 $2^{-I-}$ at E15). Of interest, we observed no evidence for senescence based on the absence of p21 or heterochromatin foci in these cells (data not shown). As Mdm2 invalidation is expected to activate p53, double AMH-p53 staining was performed at E15. In control testes (Cre-), hardly any $\mathrm{AMH}$-positive cells expressed detectable levels of p53, whereas in SC-Mdm2 $2^{-1-}$ testes, we observed that many $\mathrm{AMH}$-positive cells were clearly stained for p53 (Figure 5).
To clarify the identity and fate of the cells remaining in the absence of SCs, germ cell and Leydig cell populations were analyzed in developing SC-Mdm2 $2^{-1-}$ testes. Germ cells were identified using DDX4 staining (Figure 6) at E15 and P1. As expected, they aggregated in the cords in the control testes. A similar gathering of germ cells (despite the absence of cords or lack of SCs) was retrieved in E15 and E16 testes in SC-Mdm2 ${ }^{-/}$testes; subsequently, germ cells tended to be more dispersed throughout the testis (E18 and P1). Surprisingly, we could still observe many DDX4-positive cells in P1 testes, indicating that the loss of the supporting SCs did not immediately trigger germ cell death. As SCs are believed to produce a meiosis-repressing environment for germ cells during fetal life, we analyzed the possible presence of the meiotic marker, SYCP3 (Figure 6). In control testes, SYCP3positive cells were virtually absent, whereas in SC-Mdm2 ${ }^{-/-}$ testes, we detected numerous SYCP3-positive cells, all equally positively stained for DDX4. A close examination of the localization of SYCP3 using immunofluorescence (Figures 6i and j) indicated that SYCP3 formed fine threads in the germ cell nuclei, probably along the chromosomal axis, as expected in meiotic cells. Leydig cells were detected using $3 \beta \mathrm{HSD}$ staining (Figure 7). As expected, they were retrieved between the cords in the control testes and formed well-organized clusters around birth. In SC-Mdm2 ${ }^{-/-}$ 


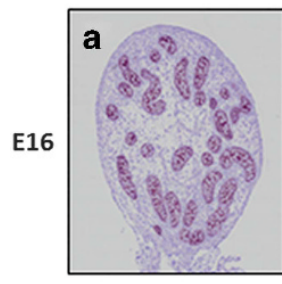

Cre-
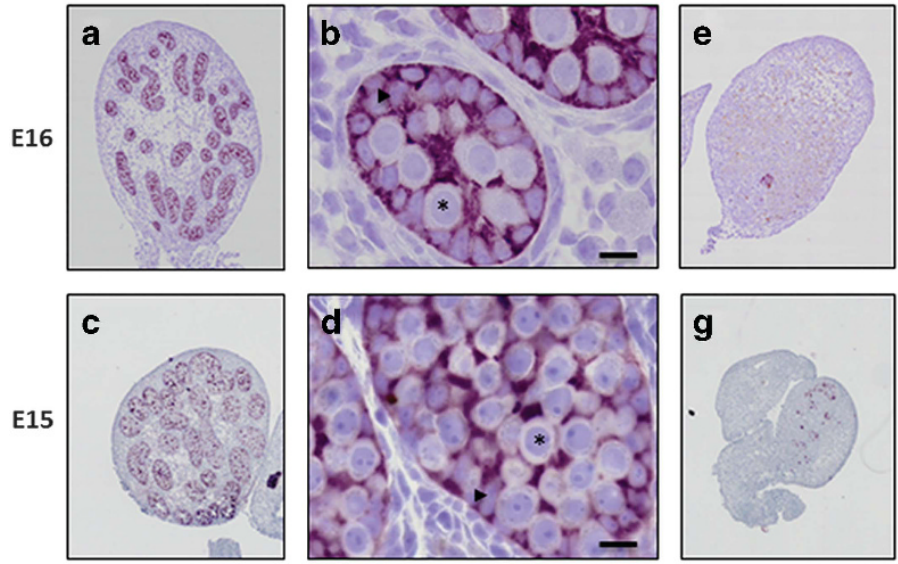

SC-Mdm2-/-
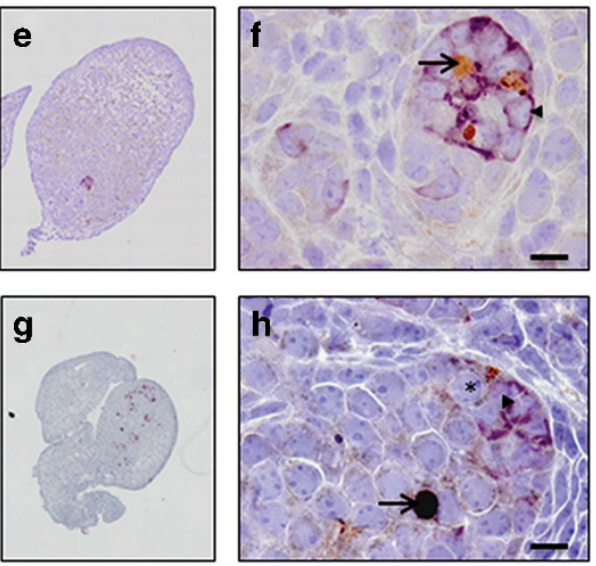

i

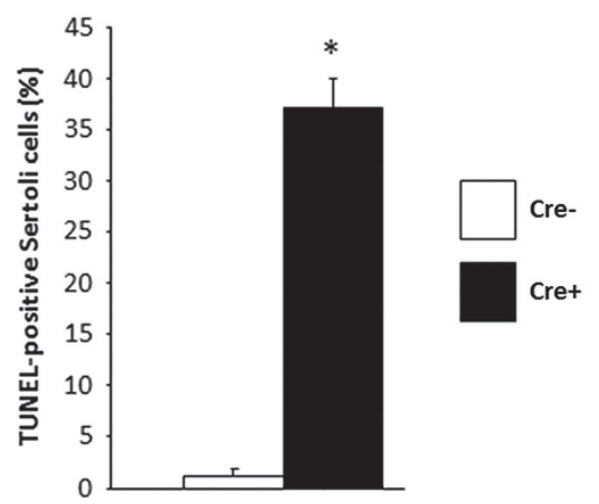

Figure 4 Loss of testicular cords during development is associated with SC apoptosis. Double AMH (purple)/TUNEL (brown) staining was performed with testes at E15 and E16 from control (Cre- a-d) and SCMdm2 ${ }^{-1-}(\mathbf{e}-\mathbf{h})$ embryos. Left panels (a, c, e, g: low magnification) represent an overview of a representative section of the testes (cartography). Right panels (b, d, f, h: high magnification) represent testicular cords at high magnification. AMH and TUNEL staining were used to reveal apoptotic SCs. A normal cord-like structure was observed in the control testes with SCs surrounding gonocytes. A pronounced loss of AMH staining was observed in SC-Mdm2 ${ }^{-1-}$ and the few remaining AMH-positive cells were frequently positive for TUNEL staining as well, indicating that apoptosis occurred mainly in SCs at these stages. Arrowheads point to healthy SCs (b, d and f, h), arrows point to apoptotic SCs (f, h: double purple/brown positive) and asterisks indicate germ cells or gonocytes. Bars represent $10 \mu \mathrm{m}$. (i) Measurement of SC apoptosis. The percentage of cells positive for both AMH and TUNEL out of total AMH-positive cells was determined at E15 in Cre- $(n=3)$ and SC-Mdm2 ${ }^{-/-}(n=5)$ testis. Data shown as mean $+/-$ S.E.M. Statistical analysis: Mann-Whitney test $\left({ }^{*} P<0.05\right)$

testes, the density of Leydig cells was normal. However, they did not form tight clusters. Interestingly, these cells were still retrieved in adult mutant testes that appeared literally packed with $3 \beta \mathrm{HSD}$-positive cells. This clearly indicated that the presence of SCs was dispensable for Leydig cell maintenance in this model.

To verify the implication of the $p 53$ tumor suppressor gene in the phenotype, we created a new line by introgressing the SC Mdm2 invalidation in the $\mathrm{p} 53^{-1-}$ line, as described in Materials and Methods ( $\mathrm{p}^{2} 3^{-/-}$being normally fertile). Mating was conducted until at least four individuals of each genotype of interest and their respective controls were obtained (Table 1). As expected, SC-Mdm2 $2^{-/} \mathrm{p} 53^{+/+}$were infertile with the same phenotype as SC-Mdm2 ${ }^{-1-}$, whereas their controls Cre-p53 $3^{+/+}$were fertile. Conversely, SC-Mdm2 ${ }^{-/-}$lacking p53

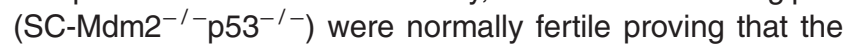
phenotype due to Mdm2 invalidation involves p53. One p53 allele (SC-Mdm2 $2^{-/} p 53^{+/}$) is sufficient to maintain the infertility phenotype.

\section{Discussion}

To date, few studies have examined the critical factor for SC survival and the development of a gonad devoid of SCs. We report here that Mdm2 is critical to prevent SC apoptosis and that its specific invalidation triggers a rapid loss of this lineage in testes. Without SCs, Leydig cells persisted, albeit with reduced steroidogenic activity and germ cells did not differentiate properly and only survived a few days.

Mdm2 is a key regulator of p53-mediated apoptosis and is proven to be a major downregulator of p53 in many cell types such as kidney cells, ${ }^{18}$ cardiomyocytes, ${ }^{19}$ neuronal cells, ${ }^{20}$ smooth muscle cells ${ }^{21}$ and hepatocytes. ${ }^{22}$ In testes, the role of Mdm2 has already been documented in germ cells. Mdm2 is one mechanism leading to p53 inactivation in male GCs. ${ }^{23}$ It is also suggested that p53 mediates spermatogonial apoptosis after DNA damage ${ }^{24}$ or overheating. ${ }^{25}$ Contrary to GCs, SC apoptosis is poorly documented as it is suspected that this phenomenon is rare. p53 was suggested to be involved in an intrinsic apoptotic program in SCs, but poorly active. ${ }^{5}$ 
Cre-

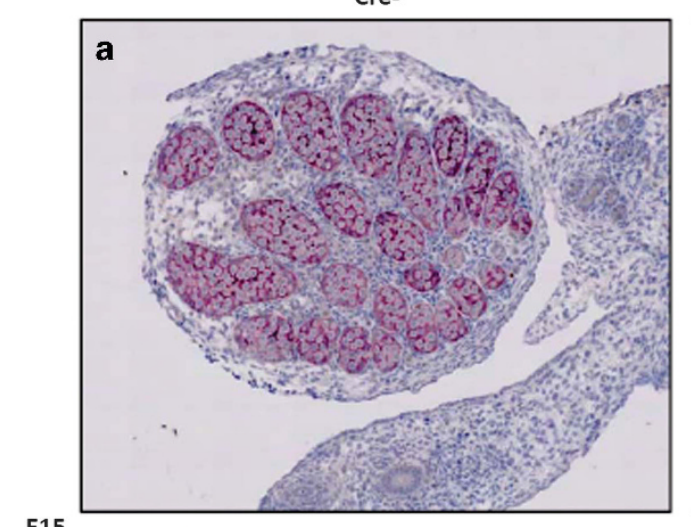

E15

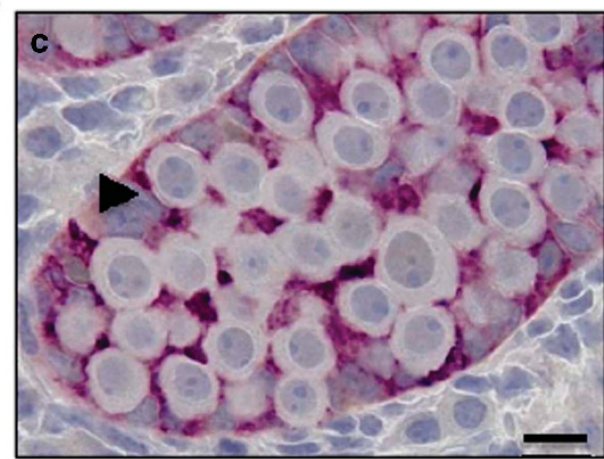

SC-Mdm2-/-
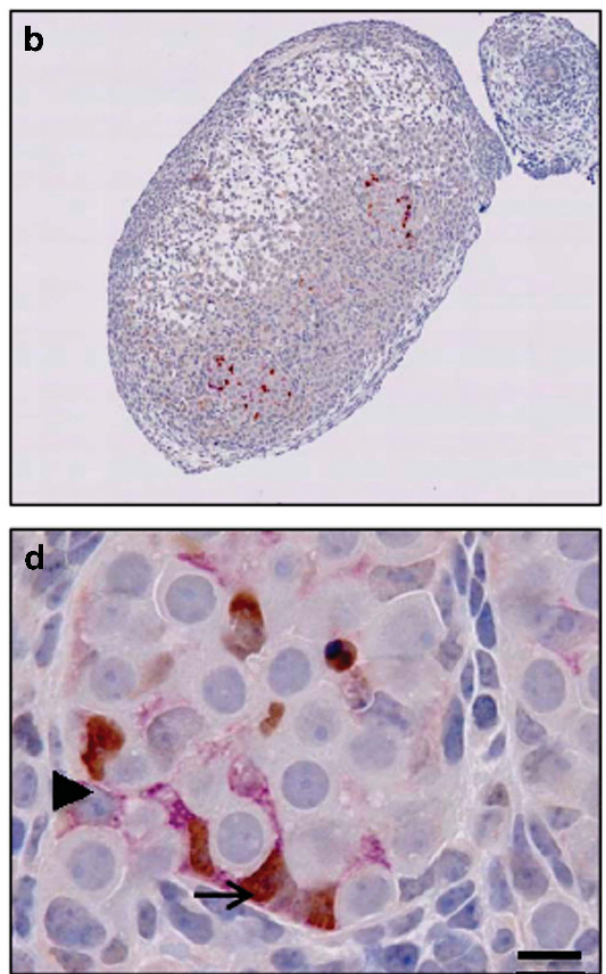

Figure 5 SC apoptosis is correlated with p53 activation. The activation of P53 was investigated in SCs at E15 in control (Cre-) (a, c) and SCMdm2 ${ }^{-/-}$(b, d) testes through double p53/AMH immunostaining. Upper panel represents a global view of a testis section and lower panel a higher magnification of testicular cords. No p53 was observed in control SCs (a, c), while many p53-positive cells (brown) were detected in cord-like structures in SC-Mdm2 ${ }^{-1-}$ (b, d). Interestingly, most were clearly positive for AMH staining (purple) as well. Arrowheads point to p53-negative SCs (c and d) and arrows point to p53-positive SCs (d: double positive). Bars represent $10 \mu \mathrm{m}$

E15
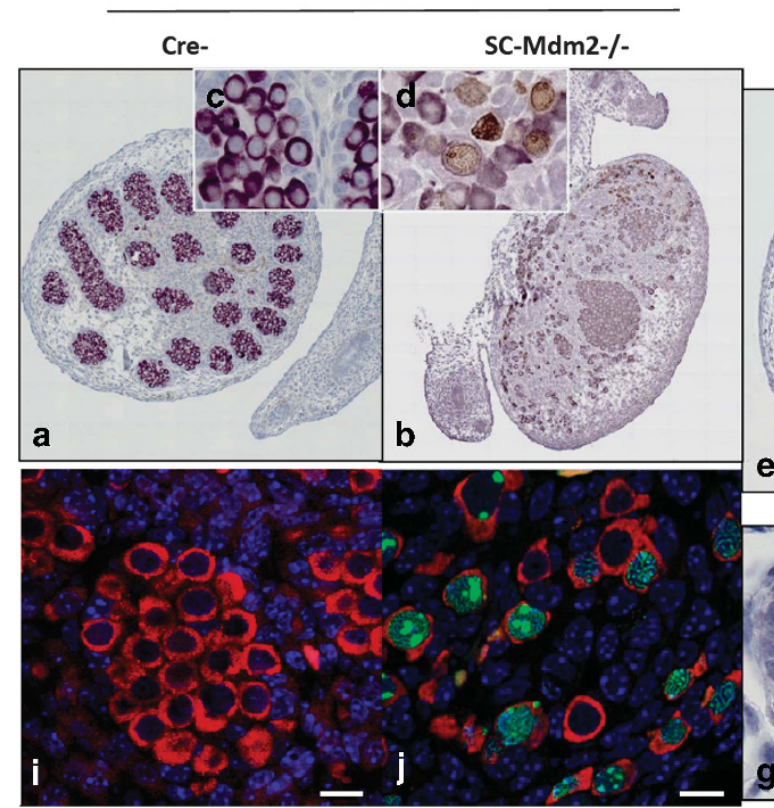

P1

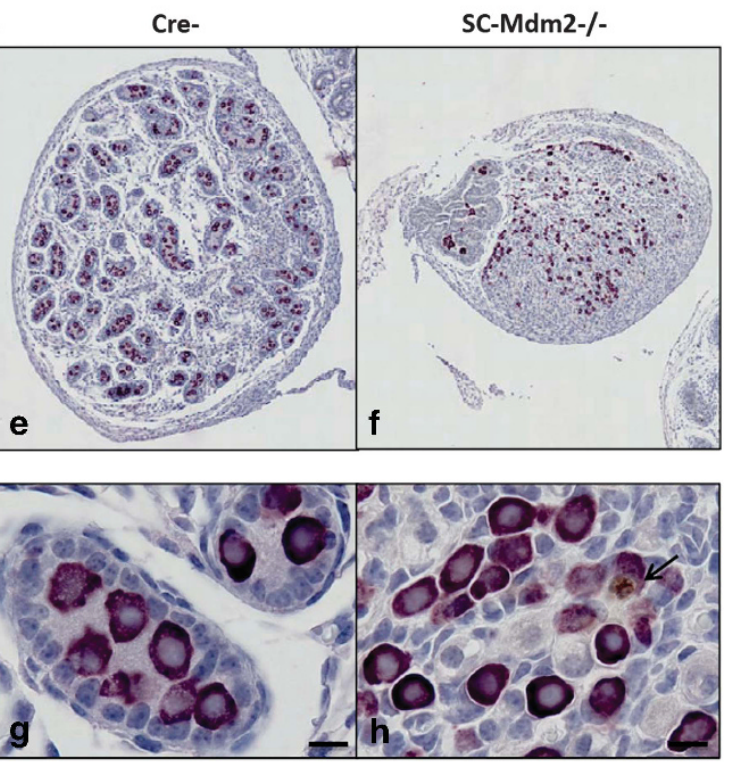

Figure 6 Maintenance of germ cells and premature meiotic entry in absence of SC. DDX4 was investigated by immunostaining (purple) or immunofluorescence (red) in E15 $(\mathbf{a}-\mathbf{d}, \mathbf{i}, \mathbf{j})$ and $\mathrm{P} 1(\mathbf{e}-\mathbf{h})$ testes from control (Cre-) and SC-Mdm2 ${ }^{-l-}$ animals to follow the germ cell population. DDX4/SYCP3 double immunostaining was performed in E15 testes: immunohistochemistry (a-d: purple for DDX4 / brown for SYCP3; c, d insets provide a higher magnification of germ cells), and immunofluorescence (i, j: DDX4 in red, SYCP3 in green forming obvious filaments in germ cell nuclei) indicated that no SCYP3-positive cells were present in the control testes, while many were retrieved in the SC-Mdm2 $2^{-1-}$ testes. Double DDX4 (purple)/cleaved caspase3 (brown) immunostaining was performed in P1 testes. Upper panels (e, $\mathrm{f}$ ) represent a global view of a testis section and lower panels a higher magnification $(\mathbf{g}, \mathbf{h})$. In both control and SC-Mdm2 ${ }^{-1}$ testes, numerous germ cells and few apoptotic cells were retrieved (i.e., positive for caspase 3 : in $\mathrm{H} 7$, the arrow points to an apoptotic germ cell). Bars represent $10 \mu \mathrm{m}$ 
Cre-
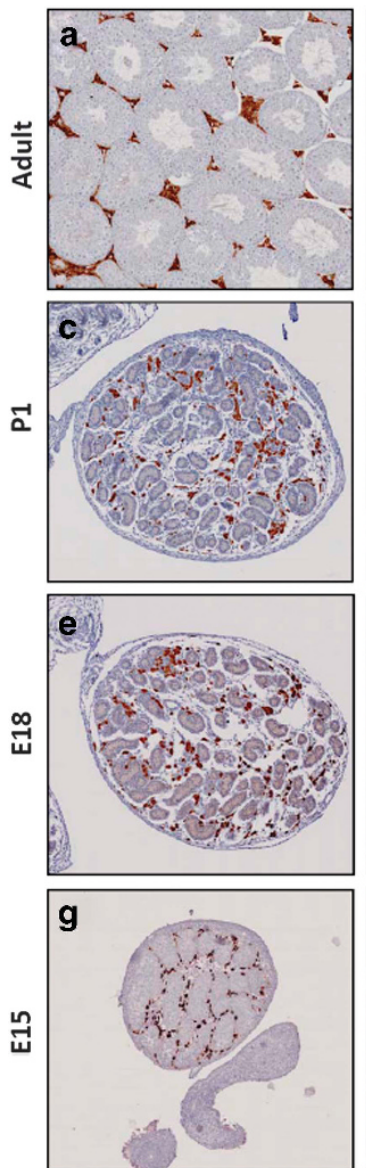

re-
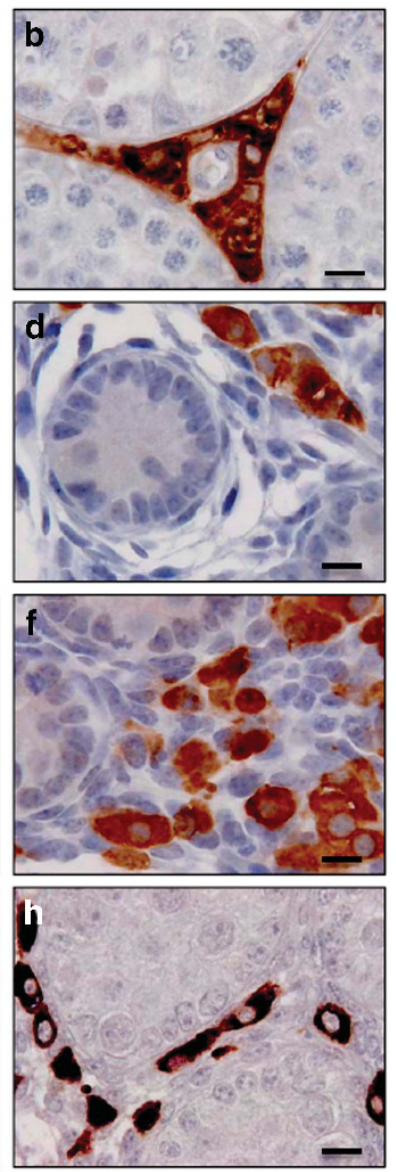

SC-Mdm2-/-
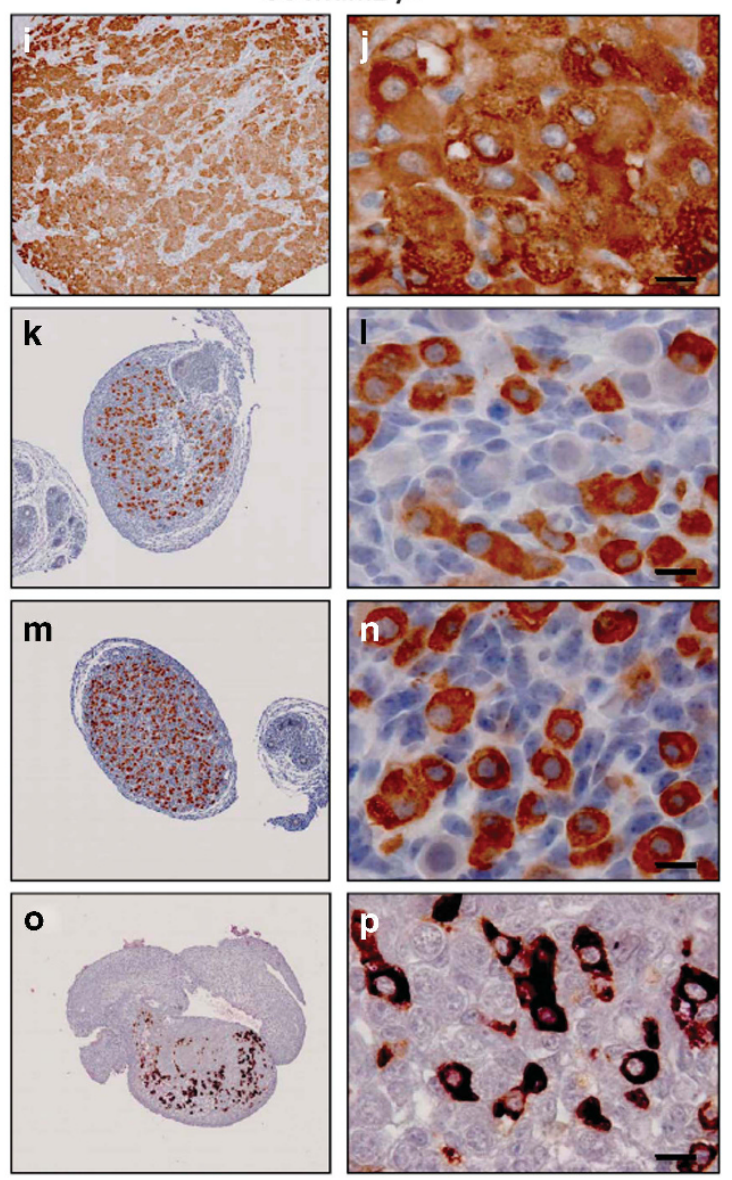

Figure 7 Maintenance of Leydig cells in absence of SCs. 3/HSD staining (brown) in E15, E18, P1 and adult controls (Cre-) (a to h) and SC-Mdm2 ${ }^{-1-}$ (i to p) testes detected Leydig cells. Left panels (low magnification: a, c, e, $\mathbf{g}$ for Cre- and i, $\mathbf{k}, \mathrm{m}, \mathrm{o}$ for SC-Mdm2 ${ }^{-l-}$ ) represent an overview of a representative section of the testes (cartography). Right panels represent high magnifications ( $b, \mathbf{d}, \mathbf{f}, \mathbf{h}$ for Cre- and $\mathbf{i}, \mathbf{k}, \mathrm{m}, \mathrm{o}$ for $\mathrm{SC}-\mathrm{Mdm} \mathrm{2}^{-/}$). Numerous Leydig cells were retrieved in both genotypes at all ages studied. Bars represent $10 \mu \mathrm{m}$

Table 1 Individual male number (\#) and fertility status tested with 2 or 4 normal females (f), of the three genotypes corresponding to the introgression of SC-

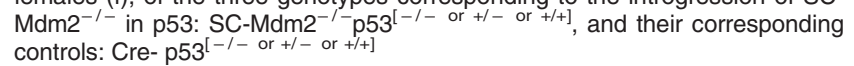

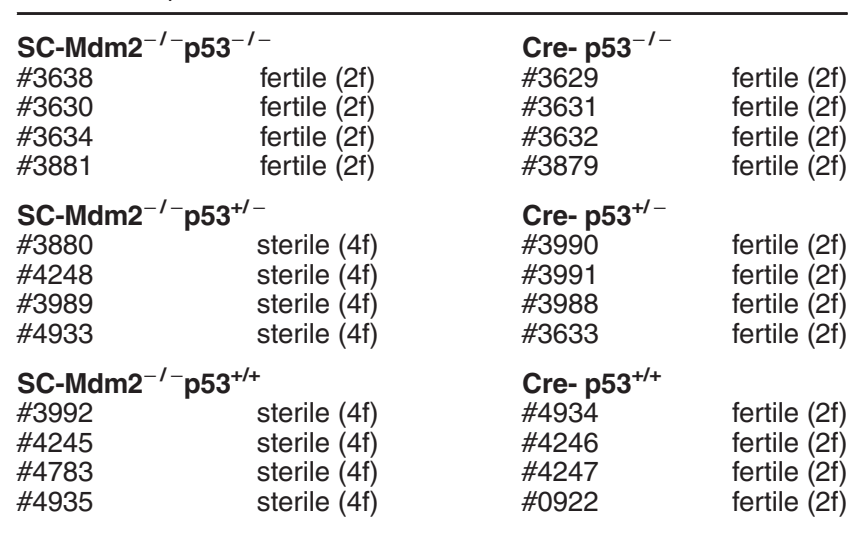

Males are contemporary

Nevertheless, the role of Mdm2 in SCs had not been examined prior to this work. The inactivation of Mdm2 using AMH-Cre led to a rapid increase in the $p 53$ protein and apoptotic markers triggering an almost total loss of SCs during fetal life.
As expected, this phenotype was alleviated when p53 was

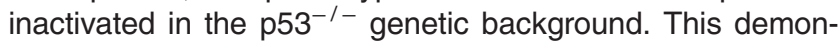
strates that p53 activity is strongly repressed in fetal SCs, and may explain the relative poor radiosensitivity of this cell type. ${ }^{26}$ As p53 is expressed in various testicular cells (and not only SCs), we cannot exclude the p53 effect in other testicular cell types leading to SC apoptosis. Targeted deletion in SCs (using p53 $3^{\text {loxP/loxP27 }}$ ) would allow to reach this point.

Fetal SCs are critical for the masculinization of the embryo, both indirectly through androgen production by LC and directly as they produce $\mathrm{AMH}$, the hormone inducing the regression of the female genitalia. We report here that SC-Mdm2 ${ }^{-1-}$ males displayed a pronounced decrease in AMH staining as early as E15. The extra duct persisting at adulthood in those mice is probably due to this drop. This lack of female duct regression has been observed previously in AMHR2KO and AMHKO males. ${ }^{28,29}$

SCs are essential for the differentiation of fetal Leydig cells. ${ }^{30}$ Of interest, we report here that even in the absence of SCs and testicular cords, LC were observed in adult testes. This suggests that SCs are dispensable for the increase and maintenance of the LC population during late fetal and postnatal life. Future work will definitively need to address the nature of the numerous steroidogenic cells observed in 
$\mathrm{SC}-\mathrm{Mdm}^{-1-}$. It is also noticeable that SC-Mdm2 $2^{-/-}$adult testes produced low levels of androgens, according to the testosterone assay and the measurement of the expression of steroidogenic enzymes. This decrease in testosterone production also probably occurred perinatally, as a decrease in ano-genital distance was observed in SC-Mdm2 ${ }^{-/-}$males. Although ano-genital distance was recently reported to conserve some degree of plasticity at adulthood, ${ }^{31}$ most of it is determined by testosterone production during late fetal life. Altogether, this proves that the presence of SCs is critical for sustaining LC activity and the production of androgens during both fetal and post-natal life. Some androgens were probably produced during the development of SC-Mdm2 $2^{-/-}$males, as the male genitalia were formed properly (e.g., presence of epididymis), and testicular descent, which is partially dependent upon androgens, occurred correctly. Testes are indeed formed in the abdominal cavity during fetal life and descend to reach a scrotal position in post-natal life. This depends on the production of two main LC hormones: first, INSL3, a peptide involved in the initial steps of the descent, and second, testosterone. ${ }^{32}$ We observed no cryptorchidy in SC-Mdm2 $2^{-1}$ males, which proves that enough testosterone and INSL3 were produced during fetal life. Thus, this secretion of LC is probably not dependent upon SC regulation.

Quite surprisingly, we observed that the loss of SCs did not trigger an immediate extinction of the germ lineage. In SC$\mathrm{Mdm}^{-1-}$, numerous germ cells were retrieved in neonatal testes several days after SC loss. However, germ cells were completely lost at adulthood confirming the absolute requirement of a supporting lineage for the long-term maintenance of germ cells. Fetal SCs are known to govern the orientation toward the male fate of germ cells through the production of Fgf9 and Cyp26b1, and thus to prevent meiotic entry during fetal life. ${ }^{33}$ In this context, our report of a premature meiotic entry is not surprising. However, the sex of germ cells is determined between E12 and E14, so one would not expect meiotic entry owing to a late loss of SCs (i.e., at E15). We may thus consider that SCs are required both to impose and to maintain a male fate in germ cells. In addition, the seemingly proper differentiation of LC and the altered one of germ cells fits well with fetal LC differentiation occurring prior to germ cell differentiation (i.e., determination of fate during fetal life).

Very recently, another study successfully produced SCdeficient testes. ${ }^{34,35}$ This work used the diphtheria toxin expressed by $\mathrm{SCs}$ and the same $\mathrm{AMH}$-Cre system as in our work. Our SC-Mdm2 $2^{-1-}$ model proposed here is complementary as it precludes the risk related to using a toxin with possible side effects. Moreover, Rebourcet and colleagues indicate a variable phenotype with, in most cases (95\%), a mere $60 \%$ reduction in the size of adult testes, possibly owing to a partial ablation of SCs in response to expression of the toxin. The invalidation of Mdm2 thus offers a more efficient and reproducible ablation of SCs, as we systematically obtained (around 30 males examined for the entire study) a $95 \%$ reduction in testis weight. The overall conclusions of both studies converge toward SCs being required to sustain germ and Leydig cell activity with a total loss of germ cells and the presence of a population of LC in adult testes. A slight difference related to the masculinization (e.g., differentiation of epididymis and vas deferens owing to testosterone production) was observed that did not seem to occur following expression of the toxin, whereas it is obvious following Mdm2 invalidation. We believe this may be due to the partial loss of $\mathrm{SC}$ in the former system. Finally, these authors also reported the persistence of SOX9-positive cells in the rete area, as observed here, due to epithelial cells in the rete only partially expressing Cre.

As a whole, our work provides a clear demonstration of the crucial role of Mdm2/p53 in the regulation of SC apoptosis and opens new possibilities for studying the role of this cell type, thanks to efficient ablation during fetal life. Future works will need to characterize the precise kinetics of dysfunctions in LC in the absence of SCs.

\section{Materials and Methods}

Animals. Mice were fed a standard laboratory diet and tap water ad libitum, and maintained under $12 \mathrm{~L}: 12 \mathrm{D}$ photoperiods in a temperature-controlled room $\left(21-23^{\circ} \mathrm{C}\right)$. All animal studies were conducted in accordance with the guidelines for the care and use of laboratory animals issued by the French Ministry of Agriculture and with the approval of a local ethical committee (number 2011-12-3, Comité d'Ethique en Expérimentation Animale Val de Loire - $n^{\circ}{ }^{19}$ ). All efforts were made to minimize animal stress and suffering.

Generation of SC-Mdm2 ${ }^{-1-}$ and SC-Mdm2 ${ }^{-1-} \mathrm{p}^{-1-}$ and their respective controls. $\mathrm{Mdm} 2^{\mathrm{LL}}$ mice were previously described by Grier et al..$^{36}$ and contain a floxed Mdm2 allele with a loxP site in intron 4, followed by a neomycin cassette, and a second loxP site in intron 6 . Recombination yields an Mdm2 allele lacking exons 5 and 6 (Mdm2[ $\delta$ exons5/6]) after the Cre recombination event, resulting in a loss of most of the p53-binding domain. ${ }^{36} \mathrm{Mdm} 2^{\mathrm{LL}}$ were crossed with heterozygous AMH-Cre mice on a C57BL/6 background, and the resulting Cre $+\mathrm{Mdm}^{-1+}$ offspring were backcrossed to $\mathrm{Mdm} 2^{\mathrm{LL}}$ mice to obtain $\mathrm{Cre}+\mathrm{Mdm}^{-{ }^{-1}}$, so called SC-Mdm2 ${ }^{-I-}$; controls were contemporary Cre-Mdm2 $2^{\mathrm{LL}}$ littermates, called Cre- here for simplicity.

p53 $3^{-1-}$ (null) mice were obtained from the Jackson laboratory (Sacramento, CA, USA) and were normally fertile. Cre+Mdm2 $2^{-1-}$ females were bred with $\mathrm{p}_{5} 3^{-1-}$ males, and the resulting $\mathrm{Cre}+\mathrm{Mdm}^{-/+} \mathrm{p} 53^{-/+}$offspring were intercrossed to obtain homozygous mice for invalid Mdm2 alleles ( $\mathrm{Mdm}^{-1-}$ ), followed by intercrossing to obtain males with key genotypes: SC-Mdm2 ${ }^{-1-} \mathrm{p} 53^{-1+}$; SC-Mdm2 ${ }^{-1-} \mathrm{p} 53^{-1-}$; SC-

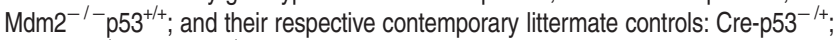
Cre-p53 $3^{-I-} ; \mathrm{Cre}^{\mathrm{p} 53^{+/+}}$.

A high predisposition to malignancy was described for homozygous $\mathrm{p} 3^{-/-}$, with a greatly accelerated rate of tumorigenesis. ${ }^{37}$ To avoid the risk of cancer, we used these mice for breeding and experiments before the age of 3.5 months.

Male fertility test. For each genotype of interest $\left(\mathrm{SC}-\mathrm{Mdm}^{-1-}\right.$, SC-Mdm2 ${ }^{-/} p 53^{-/+}$, SC-Mdm2 $2^{-1-} p 53^{-1-}$, SC-Mdm2 ${ }^{-1-} \mathrm{p} 53^{+/+}$and heterozygous SC-Mdm2 ${ }^{-/+}$), each adult male (at least four per genotype) was mated with two or four primiparous Swiss female mice.

Mouse genotyping. PCR genotyping of Cre, Mdm2 and p53 alleles have been described previously (Lécureuil et al., ${ }^{17}$ Montes et al. ${ }^{15}$ and Jones et al., ${ }^{16}$ respectively). DNA was extracted using the Tissue PCR Kit (Sigma-Aldrich, Saint Quentin Fallavier, France). GABR detection (200 bp) was used to control DNA quality.

To verify that excision was restricted to the testes, DNA was extracted from various tissues, including testes from prepubertal mice, and PCR was performed using primers previously described ${ }^{36}$ to detect the deleted allele lacking exons 5 and 6 (Mdm2[ $\delta$ exons5/6]): forward: 5'-TGTGGAGAAACAGTTACTTC-3'; reverse 5'-TGAG ATGAGTCAAAGCCTGG-3'. The annealing temperature was $50^{\circ} \mathrm{C}$.

\section{Gene expression analysis}

RNA extraction: Total RNA was isolated from whole testes (adult or P10) and from SC-enriched fractions obtained at P10 and prepared as described previously ${ }^{38}$ using RNAble reagent (Eurobio, Courtaboeuf, France). RNA $(1 \mu \mathrm{g})$ was reversetranscribed using the RNeasy kit (QIAGEN, Courtaboeuf, France) according to the manufacturer's instructions (the kit includes genomic DNA elimination with DNAse). The sample with RNA but without RT (RT - ) was the negative control. 
RT-PCR for Mdm2 mRNA detection: Classic PCR was performed with Taq polymerase from Eurobio to detect Mdm2 mRNA in SC-enriched fractions. Mdm2 mRNA-specific primers (band at $180 \mathrm{bp}$ ), described in a previous study ${ }^{39}$ were: forward 5'-CGGAAGARGCGCGGAAAGTA- 3'; reverse $5^{\prime}$-TTCCGAAGCTGGA ARCTGTGAGGTGC- $3^{\prime}$. The annealing temperature was $60^{\circ} \mathrm{C}$. For actin detection (band at $411 \mathrm{bp}$ ), used to control DNA quality, the primers were: forward: 5' TAC GAC CAG AGG CAT ACA GG 3' reverse: 5' TGA CCC AGA TCA TGT TTG AGA $3^{\prime}$. The annealing temperature was $55^{\circ} \mathrm{C}$.

Quantitative real-time PCR analysis for the investigation of testicular steroidogenesis: Three steroidogenic genes were analyzed using the TaqMan assay, with primers and probes inventoried by Applied Biosystems (Fisher Scientific, IIlkirch, France): StAR (Steroidogenic acute regulatory protein, Mm00441558_m1); P450scc -Cyp11a1- (cytochrome P450 side-chain cleavage enzyme, Mm00490735_m1); P450c17 -Cyp17a1- (steroid $17 \alpha$ hydroxylase/17,20 lyase cyrochrome P450c17, Mm00484040_m1). PCR reagents were all purchased from Applied Biosystems (Fisher Scientific) and real-time PCR was carried out in accordance with the manufacturer's instructions in a final volume of $25 \mu \mathrm{l}$ (samples were run in triplicate). Fluorescence was detected on an iCycler Bio-Rad apparatus (Bio-Rad, Marnes la Coquette, France). Negative controls (RT - and $\mathrm{H}_{2} \mathrm{O}$ ) were run for every primer/probe combination. Normalization was performed using two internal standards, $\beta$-actin (Mm00607939_s1) and Gapdh (Mm99999915_g1) from the same sample, and the normalized cDNA was compared between the two genotypes.

Blood collection and hormonal assay. Around $500 \mu \mathrm{l}$ of blood were obtained by retro-orbital sampling in anesthetized mice (with diazepam and ketamine), and collected in a tube containing EDTA.

Plasma testosterone levels: Mice were treated with an intraperitoneal injection of $15 \mathrm{IU}$ per animal of human chorionic gonadotropin (Chorulon, MSD Santé Animale, Beaucouze, France). Blood was collected before (basal level) and $2 \mathrm{~h}$ after injection (stimulated level). The plasma was stored at $-20^{\circ} \mathrm{C}$ until tritiumbased testosterone competitive radio-immunoassays, which are carried out regularly in our lab, were performed in our lab as described previously for other transgenic lines. ${ }^{40}$ The sensitivity of the assay was $0.125 \mathrm{ng} / \mathrm{ml}$ and the intraassay coefficient of variation was $7.5 \%$. Briefly, samples (two dilutions per sample) or testosterone dilutions (to determine the range) were incubated for $1 \mathrm{~h}$ at $40^{\circ} \mathrm{C}(0.1$ $\mathrm{M}$ phosphate buffer with $0.1 \%$ gelatin) with tritiated testosterone plus the antitestosterone antibody. A secondary antibody was then added and the mixtures incubated overnight at $4{ }^{\circ} \mathrm{C}$. Immuno-precipitation was then performed with PEG (PolyEthyleneGlycol) 4000 and the radioactivity counted (Packard C2900, TriCarb, PerkinEImer, Villebon S/Yvette, France).

Plasma FSH levels: Plasma FSH levels were determined in $100 \mu \mathrm{l}$ aliquots using a double Ab method and a RIA kit (rFSH RIA), kindly supplied by the National Institutes of Health (Dr A. F. Parlow, National Hormone and Peptide Program, Torrance, CA, USA). Rat FSH antigen (NIDDK-rFSH-I) was labeled with ${ }^{125}$ I using the chloramine-T method and the hormone concentration was expressed using the rat FSH reference preparation (NIDDK-rFSH-RP-2) as the standard. Intraassay and interassay coefficients were less than $7 \%$ and $10 \%$, respectively. The sensitivity of the assay was $0.125 \mathrm{ng} / 100 \mu \mathrm{l}$.

Plasma LH levels: Plasma LH levels were determined in $100 \mu$ aliquots using a double Ab method and a RIA kit (mLHRia), kindly supplied by the National Institutes of Health (Dr A. F. Parlow, National Institute of Diabetes and Digestive and Kidney Diseases, National Hormone and Peptide Program). Rat LH-I-10 (AFP-11536B) was labeled with ${ }^{125}$ using the chloramine-T method and the hormone concentration was expressed using the mouse LH reference preparation (AFP-5306 A) as the standard. Intraassay and interassay coefficients were less than $7 \%$ and $10 \%$, respectively. The sensitivity of the assay was $4 \mathrm{pg} / 100 \mu \mathrm{l}$.

Histology and immuno-detection of AMH, DDX4, 3 $\beta$ HSD, C-CASPASE3, SYCP3 and p53. Testis histology (seminiferous tubule organization) was analyzed after fixing in Bouin's fluid and embedding in paraffin. For microscopic observation, $4-\mu \mathrm{m}$ sections were stained with hematoxylin.

Immunostaining was performed as described previously ${ }^{41}$ with minor modifications. Fetal, postnatal and adult testes were fixed overnight in 10\% neutral formalin (Carlo Erba Reagents, Val de Reuil, France) before being dehydrated, embedded in paraffin wax and cut into $5-\mu \mathrm{m}$ sections. Adult testes were stained with hematoxylin and eosin; fetal and postnatal testes were used for immunostaining. The primary antibodies used in this study were either rabbit polyclonal anti-DEAD/H box polypeptide 4 (DDX4/NASA; 1:200, Abcam, Paris, France), rabbit polyclonal anti- cleaved caspase-3 (1:200, Cell Signaling/Ozyme, Montigny-Le-Bretonneux, France), goat polyclonal anti-AMH (1: 200, Santa Cruz Biotechnology, Heidelberg, Germany), mouse monoclonal anti-3betaHSD (1: 200, Transgenic Inc., Chuo-Ku, Kobe, Japan), mouse monoclonal anti-SYCP3 (Abcam 1/200), mouse monoclonal anti-P21 (1: 200, BD Biosciences, le Pont de Claix, France) or rabbit polyclonal antiTP53 (1/500, Novocastra, Leica Microsystemes, Nanterre, France). The same protocol was used for antigen retrieval. After testis section dewaxing and rehydration, antigen retrieval was performed in HIER citrate buffer pH 6 (Zytomed, Diagomics, Blagnac, France) in an autoclave (Retriever 2100, Proteogenix, Mundolsheim, France). Sections were then washed in distilled water and incubated for $15 \mathrm{~min}$ in 3\% $\mathrm{H}_{2} \mathrm{O}_{2}$ at room temperature. After $30 \mathrm{~min}$ in $2.5 \%$ normal Horse serum (Vector laboratories, Eurobio, Les Ulis, France), primary antibodies diluted in PBS were incubated for $1 \mathrm{~h}$ at $37^{\circ} \mathrm{C}$. Primary antibodies were revealed using the secondary antibody IMPRESS kit (Vector Laboratories, Eurobio). Peroxidase activity was visualized using either 3,3'-diaminobenzidine (brown) or vip (purple) as a substrate. Sections were counterstained with hematoxylin. TUNEL staining was performed using the Apoptag peroxidase kit (MP Biomedicals, Illkirch, France) in accordance with the manufacturer's recommendations. For cell counting, at least 300 cells were counted in three different sections for each testis. For immunofluorescence detection, primary antibodies were detected with specific secondary antibody species Alexa Fluor 488- and Alexa Fluor 594-conjugated antibodies (1:500, Life Technologies, Saint Aubin, France).

Statistical analysis. All data are presented as means \pm S.E.M. To compare means between two groups, the Student's $t$ test or the Mann-Whitney $U$ test, in case of differences in variance (Fisher test), was used. Other comparisons were performed using a two-way ANOVA followed by the Bonferroni post-test. $P<0.05$ was considered significant.

\section{Conflict of Interest}

The authors declare no conflict of interest.

Acknowledgements. We would like to thank Claude Cahier and Deborah Crespin for the animal facilities. Special thanks go to Christophe Gauthier for the testosterone assays, Isabelle Gibert, Peggy Jarrier and Linda Beauclair for the genotyping, Mrs Arlette Gerard for the FSH and LH assays and Marie Françoise Pinault for her help managing the pictures. Florian Guillou is thanked for providing AMH-Cre line. The English was proofread and corrected by Helen Lamprell from HSB Traductions. This work was funded by two grants from the Agence Nationale pour la Recherche ('Biodiversité, évolution des écosystemes, écosystemes productifs, agronomie' grant; 2011-2013): TimeOfLife2 and EarlyFoll.

1. Svingen $T$, Koopman $P$. Building the mammalian testis: origins, differentiation, and assembly of the component cell populations. Genes Dev 2013; 27: 2409-2426.

2. Svechnikov K, Landreh L, Weisser J, Izzo G, Colón E, Svechnikova I et al. Origin, development and regulation of human Leydig cells. Horm Res Paediatr 2010; 73: 93-101.

3. Lejeune $\mathrm{H}$, Chuzel F, Thomas $\mathrm{T}$, Avallet $\mathrm{O}$, Habert R, Durand $\mathrm{P}$ et al. Paracrine regulation of Leydig cells. Ann Endocrinol 1996; 57: 55-63.

4. Moreno SG, Dutrillaux B, Coffigny H. High sensitivity of rat foetal germ cells to low dose-rate irradiation. Int J Radiat Biol 2001; 77: 529-538.

5. Lambrot R, Coffigny H, Pairault C, Lécureuil C, Frydman R, Habert R et al. High radiosensitivity of germ cells in human male fetus. J Clin Endocrinol Metab 2007; 92 2632-2639.

6. Hall PA, Lane DP. Tumor suppressors: a developing role for p53? Curr Biol 1997; 7 R144-R147.

7. Levine AJ, Tomasini R, McKeon FD, Mak TW, Melino G. The p53 family: guardians of maternal reproduction. Nat Rev Mol Cell Biol 2011; 12: 259-265.

8. Cavallo F, Feldman DR, Barchi M. Revisiting DNA damage repair, p53-mediated apoptosis and cisplatin sensitivity in germ cell tumors. Int J Dev Biol 2013; 57: 273-280.

9. Matsui $Y$, Nagano R, Obinata M. Apoptosis of fetal testicular cells is regulated by both p53dependent and independent mechanisms. Mol Reprod Dev 2000; 55: 399-405.

10. Beumer TL, Roepers-Gajadien HL, Gademan IS, van Buul PP, Gil-Gomez G, Rutgers DH et al. The role of the tumor suppressor p53 in spermatogenesis. Cell Death Differ 1998; 5 : 669-677.

11. Levine AJ. p53, the cellular gatekeeper for growth and division. Cell 1997; 88: 323-331.

12. Prives C, Hall PA. The p53 pathway. J Pathol 1999; 187: 112-126.

13. Lavin MF, Gueven N. The complexity of p53 stabilization and activation. Cell Death Differ 2006; 13: 941-950. 
14. Marine JC, Lozano G. Mdm2-mediated ubiquitylation: p53 and beyond. Cell Death Differ 2010; 17: 93-102.

15. Montes de Oca Luna R, Wagner DS, Lozano G. Rescue of early embryonic lethality in mdm2-deficient mice by deletion of p53. Nature 1995; 378: 203-206.

16. Jones SN, Roe AE, Donehower LA, Bradley A. Rescue of embryonic lethality in Mdm2deficient mice by absence of p53. Nature 1995; 378: 206-208.

17. Lécureuil C, Fontaine I, Crepieux P, Guillou F. Sertoli and granulosa cell-specific Cre recombinase activity in transgenic mice. Genesis 2002; 33: 114-118.

18. Hilliard S, Aboudehen K, Yao X, El-Dahr SS. Tight regulation of p53 activity by Mdm2 is required for ureteric bud growth and branching. Dev Biol 2011; 353: 354-366.

19. Grier JD, Xiong S, Elizondo-Fraire AC, Parant JM, Lozano G. Tissue-specific differences of p53 inhibition by Mdm2 and Mdm4. Mol Cell Biol 2006; 26: 192-198.

20. Lovell MA, Xie C, Xiong S, Markesbery WR. Wilms' tumor suppressor (WT1) is a mediator of neuronal degeneration associated with the pathogenesis of Alzheimer's disease. Brain Res 2003; 983(1-2): 84-96.

21. Boesten LS, Zadelaar SM, De Clercq S, Francoz S, van Nieuwkoop A, Biessen EA et al. Mdm2, but not Mdm4, protects terminally differentiated smooth muscle cells from p53-mediated caspase-3-independent cell death. Cell Death Differ 2006; 13: 2089-2098.

22. Cao W, Zhang JL, Feng DY, Liu XW, Li Y, Wang LF et al. The effect of adenovirusconjugated NDRG2 on p53-mediated apoptosis of hepatocarcinoma cells through attenuation of nucleotide excision repair capacity. Biomaterials 2014; 35: 993-1003.

23. Schwartz D, Goldfinger N, Rotter V. Expression of p53 protein in spermatogenesis is confined to the tetraploid pachytene primary spermatocytes. Oncogene 1993; 8: 1487-1494.

24. Hasegawa M, Zhang Y, Niibe H, Terry NH, Meistrich ML. Resistance of differentiating spermatogonia to radiation-induced apoptosis and loss in p53-deficient mice. Radiat Res 1998; 149: 263-270.

25. Socher SA, Yin Y, Dewolf WC, Morgentaler A. Temperature-mediated germ cell loss in the testis is associated with altered expression. J Urol 1997; 157: 1986-1989.

26. Vergouwen RP, Huiskamp R, Bas RJ, Roepers-Gajadien HL, Davids JA. de Rooij DG. Radiosensitivity of testicular cells in the fetal mouse. Radiat Res 1995; 141: 66-73.

27. Marino S, Vooijs M, van Der Gulden H, Jonkers J, Berns A. Induction of medulloblastomas in p53-null mutant mice by somatic inactivation of $\mathrm{Rb}$ in the external granular layer cells of the cerebellum. Genes Dev 2000; 14: 994-1004.

28. Wu X, Arumugam R, Baker SP, Lee MM. Pubertal and adult Leydig cell function in Mullerian inhibiting substance-deficient mice. Endocrinology 2005; 146: 589-595.

29. Mishina Y, Rey R, Finegold MJ, Matzuk MM, Josso N, Cate RL et al. Genetic analysis of the Müllerian-inhibiting substance signal transduction pathway in mammalian sexual differentiation. Genes Dev 1996; 10: 2577-2587.

30. Yao HH, Whoriskey W, Capel B. Desert Hedgehog/Patched 1 signaling specifies fetal Leydig cell fate in testis organogenesis. Genes Dev 2002; 16: 1433-1440.
31. Mitchell RT, Mungall W, McKinnell C, Sharpe RM, Cruickshanks L, Milne L et al. Anogenital distance (AGD) plasticity in adulthood: Implications for its use as a biomarker of fetal androgen action. Endocrinology 2015; 156: 24-31.

32. Bay K, Main KM, Toppari J, Skakkebæk NE. Testicular descent: INSL3, testosterone, genes and the intrauterine milieu. Nat Rev Urol 2011; 8: 187-196.

33. Bowles J, Feng CW, Spiller C, Davidson TL, Jackson A, Koopman P. FGF9 suppresses meiosis and promotes male germ cell fate in mice. Dev Cell 2010; 19: 440-449.

34. Rebourcet D, O'Shaughnessy PJ, Pitetti JL, Monteiro A, O'Hara L, Milne L et al. Sertoli cells control peritubular myoid cell fate and support adult Leydig cell development in the prepubertal testis. Development 2014; 141: 2139-2149.

35. Rebourcet D, O'Shaughnessy PJ, Monteiro A, Milne L, Cruickshanks L, Jeffrey $\mathrm{N}$ et al. Sertoli cells maintain Leydig cell number and peritubular myoid cell activity in the adult mouse testis. PLoS One 2014; 9: e105687.

36. Grier JD, Yan W, Lozano G. Conditional allele of mdm2 which encodes a p53 inhibitor. Genesis 2002; 32: 145-147.

37. Jacks T, Remington L, Williams BO, Schmitt EM, Halachmi S, Bronson RT et al. Tumor spectrum analysis in p53-mutant mice. Curr Biol 1994; 4: 1-7.

38. Lécureuil C, Saleh MC, Fontaine I, Baron B, Zakin MM, Guillou F. Transgenic mice as a model to study the regulation of human transferrin expression in Sertoli cells. Hum Reprod 2004; 19: 1300-1307.

39. Montes de Oca Luna RM, Tabor AD, Eberspaecher H, Hulboy DL, Worth LL, Colman MS et al. The organization and expression of the mdm2 gene. Genomics 1996; 33: 352-357.

40. Fumel B, Guerquin MJ, Livera G, Staub C, Magistrini M, Gauthier C et al. Thyroid hormone limits postnatal Sertoli cell proliferation in vivo by activation of its alpha1 isoform receptor (TRalpha1) present in these cells and by regulation of Cdk4/JunD/c-myc mRNA levels in mice. Biol Reprod 2012; 87: 1-9.

41. Livera G, Delbes G, Pairault C, Rouiller-Fabre V, Habert R. Organotypic culture, a powerful model for studying rat and mouse fetal testis development. Cell Tissue Res 2006; 324: $507-21$.

(c) (i) $(9)$ This work is licensed under a Creative Commons Attribution-NonCommercial-NoDerivs 4.0 International License. The images or other third party material in this article are included in the article's Creative Commons license, unless indicated otherwise in the credit line; if the material is not included under the Creative Commons license, users will need to obtain permission from the license holder to reproduce the material. To view a copy of this license, visit http://creativecommons.org/licenses/by-nc-nd/4.0/

Supplementary Information accompanies this paper on Cell Death and Differentiation website (http://www.nature.com/cdd) 